\title{
Inhibitory Effects of Various Mulberry Fruits (Morus alba L.) on Related Enzymes to Adult Disease
}

\author{
Jung-Woo Chae ${ }^{1}$, Hye-Jin Park', Sun-Ae Kang ${ }^{2}$, Won-Seup Cha ${ }^{3}$, Dong-Hyun Ahn ${ }^{4}$ and Young-Je Cho ${ }^{3}$ \\ ${ }^{1}$ Gyeonggi-do Forest Environment Research Institute, Osan 447-290, Korea \\ ${ }^{2}$ School of Applied Bioscience, Kyungpook National University, Daegu 702-701, Korea \\ ${ }^{3}$ School of Food science \& Biotechndogy Food \& Bio-Industry Research Institute, Kyungpook National University, Daegu 702-701, Korea \\ ${ }^{4}$ Department of Food Science \& Technology, Institute of Food Science, Pukyong National University, Busan 608-737, Korea
}

Received March 23, 2012 /Revised July 19, 2012 /Accepted July 23, 2012

\begin{abstract}
The objective of this research was to develop the functional material of water and $60 \%$ ethanol extracts from nine kinds of mulberry fruits (Morus alba L.) that influence the inhibitory activity on angiotensin-converting enzyme, xanthine oxidase, a-amylase, and a-glucosidase. The total phenolic contents in the water extracts were over $2 \mathrm{mg} / \mathrm{g}$ in two species (Cheongilppong and Kangwon III) and five species (Daeyoupchosaeng, Cheongilppang, Kangwon III, Hihak, and Cataned) of $60 \%$ ethanol extracts. The inhibitory activity against the angiotensin-converting enzyme was determined with them. Baekwoon III was $90.9 \pm 4.5 \%$ in the water extracts, and Hihak was $81.8 \pm 4.5 \%$ in the $60 \%$ ethanol extracts. The inhibitory activity of Kuksang 20 against xanthin oxidase was about $10 \%$ in the water extracts, and Cataneo was $21.4 \pm 2.3 \%$ in the $60 \%$ ethanol extracts. Six of the species (Daeyoupchosaeng Suwonppong, Cheongilppong, Kangwon III, Hihak, and Kuksang 20) in the water extracts showed inhibitory activities against a-amylase, as 100\%, respectively. The inhibitory activity of a-glucosidase was determined for these nine species. Four species (Baekwoon III, Daeyoupchosaeng, Cheongilppong, Kangwon III, Hihak, and Kuksang 20) in the water extracts and three species (Daechoukmyeun, Kangwon III, and Kuksang 20) in the $60 \%$ ethanol extracts showed inhibition of over $20 \%$. The results revealed strong biological activity in spite of little total phenolic contents. These water and $60 \%$ ethanol extracts with high-quality biological activity from various mulberry fruits (Morus alba L.) are expected to represent good candidates for the development of antihypertentive and antidiabetes sources.
\end{abstract}

Key words : Mulberry fruits (Morus alba L.), angiotensin converting enzyme, xanthine oxidase, a-amylase, a-glucosidase

\section{서 론}

최근 급격한 생활수준의 향상과 평균수명의 연장으로 인해 고혈압과 당뇨, 중풍 등 성인병으로 고생하는 사람들이 급격 히 증가하고 있다. 성인병은 각 질병마다 발병 위험 인자가 틀리지만 이의 위험 인자로는 평균수명의 연장, 과다한 양분 섭취, 각종공해, 스트레스, 고지혈증, 비만, 흡연, 음주, 운동부 족, 불규칙적인 생활, 당뇨병 등이 큰 원인으로 작용하고 있다. 이들 성인병을 예방 혹은 치료할 수 있는 기능은 식품이나 식물체도 가지고 있다는 것이 보고되고 있으며[30], 보다 건강 하게 오래 살려는 인류의 필요성에 따라 근래에 이르러 우리 나라뿐만 아니라 세계적으로 다양한 자원으로부터 다양한 생 리기능을 가진 물질을 탐색하려는 연구가 활발히 진행되고 있는데, 그 중에서도 특히 식물자원에 포함된 화합물에 많은 관심이 집중되고 있다[21,22].

오디(mulberry)는 뽕나무과(Moracead)에 속하는 낙엽교목

*Corresponding author

Tel : +82-53-950-7755, Fax : +82-53-950-7762

E-mail : yjcho@knu.ac.kr
인 뽕나무(Morus albba L.)의 열매로서 5월부터 6월에 걸쳐 과 실의 색이 검은색 또는 자홍색을 나타낼 때 채취하여 식용하 거나 건조한 후 한약재로 사용하고 있으며, 백발을 검게 하고 소갈을 덜어주고 빈혈, 고혈압, 관절통 및 대머리 치료에 효능 이 있는 것으로 알려져 있다[18]. 또한 오디 추출물은 항당뇨 [20], 항염증[19], 항산화[2] 및 항고지혈증[14] 등의 여러 생리 적 작용을 지니고 있으며, 강장제나 진정제로 사용된 예가 있 고, 부종억제, 숙취제거 등에 사용된 것으로 기록되어 있으나, 현대의학에서는 오디의 혈당강화작용에 대한 보고가 있을 뿐 이며[15], 최근 뽕나무 부산물 중 뽕잎, 누에 및 상백피 등의 생리활성에 대한 연구가 비교적 활발하게 진행된 반면 오디에 대한 체계적인 연구는 별반 없는 상태이다.

1985년 세계보건기구의 분류에 따라 당뇨병은 인슐린 의존 형, 인슐린 비의존형 및 인슐린 요구형 등 3 가지로 나눌 수 있다. 우리나라에서는 인슐린 비의존형 당뇨병 환자가 $90 \%$ 이상이며, 역학적인 연구에 따르면 전통적인 생활방식을 고수 하는 지역의 주민에게서 인슐린 비의존형 당뇨병의 발생율이 낮고, 개발도상국에서 선진국으로 이민한 사람에게서 발생율 이 현저히 증가하는 것으로 밝혀졌다[26,28]. 당뇨, 비만, 과혈 
당증 등 탄수화물과 관련된 질병 치료를 위한 식물에서 보고 된 a-amylase 저해제는 당 단백질과 관련된 물질이 대부분이 고, 일부 한약재와 미생물을 대상으로 한 연구가 있을 뿐 식물 유래의 저해물질에 대한보고는 미흡한 형편이며 당뇨병 예방 적인 차원에서는 천연물을 이용한 항당뇨 식이의 개발은 전무 한 실정이다[9,24]. 또한 식물자원에 풍부한 페놀성 화합물이 고혈압을 유발하는 angiotensin converting enzyme과 통풍 (gout)을 유발하는 xanthine oxidase등의 성인병 유발 효소들 에 대하여 큰 저해효과를 일으킨다는 보고가 있다[1,32].

본 연구에서는 천연물을 활용한 성인병 억제 효과 연구의 일환으로 뽕나무 열매(오디) 추출물의 total phenolic compound의 함량을 측정하고, 성인병 관련효소인 혈압상승효소 (angiotensin converting enzyme), 통풍유발효소(xanthine oxidase), 혈당상승효소(a-amylase, a-glucosidase)의 활성억제 효과를 측정하여 생리활성효과를 탐색함으로써 새로운 기능 성 식품 소재 개발을 위한 기초 자료를 확보하고자 하였다.

\section{재료 및 방법}

\section{오디 추출물의 제조}

본 실험에서 사용된 오디(뽕나무열매)는 경북 상주시 소재 잠사곤충시험장에서 Table 1에서와 같이 9종을 획득하여, 이 를 건조시킨 후 분쇄하여 저온저장하면서 이용하였으며, 오디 의 물 추출물은 시료 $1 \mathrm{~g}$ 을 증류수 $200 \mathrm{ml}$ 에 넣고 액이 100 $\mathrm{ml}$ 가 될 때까지 가열 한 후 냉각하고, 에탄올 추출물은 시료 $1 \mathrm{~g}$ 을 $60 \%$ 에탄올 $100 \mathrm{ml}$ 에 가하여, 이들 모두를 $150 \mathrm{rpm}$ 에서 24 시간 교반 추출 한 뒤 $10,000 \mathrm{rpm}$ 으로 15 분간 원심분리하고, 각각의 상징액을 Whatman No. 1 여과지로 여과하여 시료로 사용하였다.

\section{Total phenolic compound 함량의 측정}

시료 추출물의 총 페놀함량은 다음과 같이 Folin-Danis법으 로 정량하였다[7]. 시료액 $1 \mathrm{ml}$ 에 $95 \%$ 에탄올 $1 \mathrm{ml}$, 증류수 $5 \mathrm{ml}$, 그리고 $1 \mathrm{~N} \mathrm{Folinciocalteu}$ 시약 $0.5 \mathrm{ml}$ 를 각각 가하여 잘 섞어주고 5 분간 발색시킨 후, $5 \% \mathrm{Na}_{2} \mathrm{CO}_{3} 1 \mathrm{ml}$ 를 가하고

Table 1. Mulberry fruits (Morus alba L.) used for experiment

\begin{tabular}{ll}
\hline Source & Scientific name of sample \\
\hline & Baekwoon III \\
& Daeyoupchosaeng \\
& Suwonppong \\
& Cheongilppong \\
& Daechoukmyeun \\
Morus alba L. & Kangwon III \\
& Hihak \\
& Cataneo \\
& Kuksang 20 \\
\hline
\end{tabular}

어두운 실온에 정치시킨 후 1 시간 이내에 $725 \mathrm{~nm}$ 에서 흡광도를 측정하여 gallic acid를 이용한 표준곡선으로 양을 환산하였다.

\section{Angiotensin converting enzyme (ACE) 활성억제 측정}

고혈압 유발효소인 $\mathrm{ACE}$ 활성억제 측정은 Cushman과 Ondetti의 방법[5]에 따라 $0.3 \mathrm{M} \mathrm{NaCl}$ 을 함유하는 $0.1 \mathrm{M}$ potassium phosphate buffer ( $\mathrm{pH}$ 8.3)에 $2.5 \mathrm{mM}$ Hippuryl-histidyl-leucine을 녹인 기질액 $0.15 \mathrm{ml}$ 에 ACE $(0.125 \mathrm{unit} / \mathrm{ml})$ $0.1 \mathrm{ml}$ 와 시료액 $0.1 \mathrm{ml}$ 를 가하고 대조구에는 시료액 대신 증 류수를 $0.1 \mathrm{ml}$ 를 첨가하여 $37^{\circ} \mathrm{C}$ 에서 30 분간 반응시키고 $1 \mathrm{~N}$ $\mathrm{HCl} 0.35 \mathrm{ml}$ 를 가하여 반응을 종료시킨 뒤 ethyl acetate 3 $\mathrm{ml}$ 를 가하고 ethyl acetate층만을 취하여 evaporating한 뒤, 그 잔사에 증류수 $2 \mathrm{ml}$ 를 가하여 효소에 의해 기질로부터 분리 되어 추출된 hippuric acid를 녹여 $280 \mathrm{~nm}$ 에서 흡광도를 측정 하여 구한 뒤 표준곡선에서 양을 환산하여 아래의 식에 의해 저해율 $(\%)$ 을 계산하였다.

$$
\text { 저해율 }(\%)=\left(1-\frac{\text { 반응구의 hippuric acid생성량 }}{\text { 대조구의 hippuric acid 생성량 }}\right) \times 100
$$

\section{Xanthine Oxidase (XOase) 활성억제 측정}

관절염 유발효소인 XOase 활성억제 측정은 Stirpe와 Corte 의 방법[32]에 따라 측정하였다. 즉 반응구는 $0.1 \mathrm{M}$ potassium phosphate buffer (pH 7.5)에 xanthine $2 \mathrm{mM}$ 을 녹인 기질액 $1 \mathrm{ml}$ 에 xanthine oxidase $(0.25 \mathrm{unit} / \mathrm{ml}) 0.1 \mathrm{ml}$ 와 시료액 0.1 $\mathrm{ml}$ 를 가하고 대조구에는 시료액 대신 증류수를 $0.1 \mathrm{ml}$ 첨가하 여 $37^{\circ} \mathrm{C}$ 에서 5 분간 반응시키고 $20 \%$ trichloroacetic acid $1 \mathrm{ml}$ 를 가하여 반응을 종료시키고 $3,500 \mathrm{rpm}$ 에서 15 분간 원심분리 하여 단백질을 제거한 후 반응액 중에 생성된 uric acid양을 $292 \mathrm{~nm}$ 에서 흡광도를 측정하여 구한 뒤 표준곡선에서 양을 환산하여 아래의 식에 의해 저해율(\%)을 계산하였다.

$$
\text { 저해율 }(\%)=\left(1-\frac{\text { 반응구의 uric acid 생성량 }}{\text { 대조구의 uric acid 생성량 }}\right) \times 100
$$

\section{a-Amylase 활성억제 효과 측정}

항당뇨활성 측정을 위한 pancreatin a-amylase 활성억제 측 정은 agar diffusion method[3]를 이용하여 측정하였다. 즉, plate는 $5 \mathrm{~g}$ 의 agar와 $5 \mathrm{~g}$ 의 soluble starch를 $500 \mathrm{ml}$ 증류수에 녹여 끓인 후, $121^{\circ} \mathrm{C}$ 로 15 분간 멸균하고 $15 \mathrm{ml}$ 씩 petridish에 붓고 식힌 뒤 $200 \mu \mathrm{g} / \mathrm{ml}$ 농도의 시료액 $0.8 \mu \mathrm{l}$ 와 효소액 0.2 $\mu \mathrm{l}(1,000 \mathrm{unit} / \mathrm{ml})$ 를 섞어 plate 위에 놓인 disc paper 위에 각각 분주하고 대조구에는 시료액 대신 증류수를 넣어 $37^{\circ} \mathrm{C}$ 에 서 3일간 배양한 후 $\mathrm{I}_{2} / \mathrm{KI}\left(5 \mathrm{mM} \mathrm{I}_{2}\right.$ in $\left.3 \% \mathrm{KI}\right) 5 \mathrm{ml}$ 를 가하여 15 분간 발색시킨 후 다음의 식으로 저해율을 계산하였다.

$$
\text { 저해율 }(\%)=\left(\frac{\text { 대조구의 면적 }- \text { 반응구의 면적 }}{\text { 대조구의 면적 }}\right) \times 100
$$




\section{a-Glucosidase 활성억제 효과 측정}

항당뇨활성 측정을 위한 a-glucosidase 활성억제 측정은 Tibbot와 Skadsen의 방법[33]에 따라 측정하였다. $50 \mathrm{mM}$ sodium succinate buffer ( $\mathrm{pH}$ 4.2)에 $\rho$-nitrophenol-a-D-glucopyranoside (PNPG)를 용해시켜 $1 \mathrm{mg} / \mathrm{ml}$ 의 농도로 기질을 만들고, 기질 $1 \mathrm{ml}$ 와 효소액 $0.1 \mathrm{ml}$ 를 혼합하고 대조구에는 증류수 $0.1 \mathrm{ml}$, 반응구에는 $200 \mu \mathrm{g} / \mathrm{ml}$ 농도의 시료 $0.1 \mathrm{ml}$ 를 넣어 $37^{\circ} \mathrm{C}$ 에서 30 분간 반응시킨 후 $1 \mathrm{~N} \mathrm{NaOH} 0.1 \mathrm{ml}$ 를 첨가 하여 발색시켰다. 이때 생성된 p-nitrophenol (PNP)은 $400 \mathrm{~nm}$ 에서 spectrophotometer를 이용하여 흡광도를 측정하였으며, 그 양은 p-nitrophenol로부터 작성한 표준곡선으로부터 구하 여 다음의 식으로 저해율을 구하였다.

$$
\text { 저해율 }(\%)=\left(1-\frac{\text { 반응구의 } \rho \text {-nitrophenol 생성량 }}{\text { 대조구의 } \rho \text {-nitrophenol 생성량 }}\right) \times 100
$$

\section{결과 및 고찰}

Total phenolic compound 함량의 측정

식물에 존재하는 많은 phytochemical 중 페놀 화합물이나 플라보노이드류는 여러 가지 식품에 널리 분포되어 있으며 [31], 이 중 페놀 화합물은 phenolic hydroxyl기를 가지기 때문 에 단백질 및 기타 거대 분자들과 결합하는 성질을 가지며, 항산화 효과, 효소억제작용 등의 여러 생리활성기능을 가진다 [11]는 보고가 있어 다양한 종류의 오디 추출물로 부터 total phenolic compound의 함량을 측정하였다(Table 2). 실험에 이 용한 9종 가운데 강원 3호의 경우 물추출물에서 $2.9 \mathrm{mg} / \mathrm{g}$ 가 량의 phenolic compound가 측정되었고, 다양한 농도의 에탄 올을 추출용매로 사용하였을 때 $60 \%$ ethanol 추출물에서 3.2 $\mathrm{mg} / \mathrm{g}$ 가량의 phenolic compound 함량으로 최대 함량을 나타 내었으며, 강원 3호가 9종의 오디 종류 중에서 가장 높은 phenolic compound의 함량을 함유하고 있는 것으로 확인되었다. 다음으로 청일뽕의 경우, 물 추출물에서 $2.2 \mathrm{mg} / \mathrm{g}$ 의 비교적
높은 농도를 나타내었으나, 첨가되는 에탄올의 농도가 20 80\%로 높아질수록 용출되는 phenolic compound의 함량 이 $1.8 ~ 2.4 \mathrm{mg} / \mathrm{g}$ 으로 높아지는 양상을 나타내었으며, $80 \%$ 에 탄올 용액에서 최대의 용출을 나타내었다. 기타 다른 종류의 오디에서도 물추출물보다 에탄올 추출물에서 용출되는 phenolic compound의 함량이 높은 것을 확인하였으며, 평균적으 로 $60 \%$ 에탄올 농도에서 최대의 용출율을 나타내는 것으로 판단하였다. 이는 곡류의 phenol성 물질이 $60 \%$ 에탄올에서 추출수율이 가장 높다는 Zielinski와 Kozlowska의 결과[35]와 유사하며, 물 보다 극성유기용매에서 페놀성 물질의 용해도가 높게 나타났다는 보고와 일치하였다. 이러한 결과를 토대로 본 연구에서는 다양한 종류의 오디 물 추출물과 페놀성 화합 물 용출 함량이 가장 높은 $60 \%$ 에탄올 추출물을 대상으로 생 리활성효과를 탐색하였다.

\section{Angiotensin converting enzyme (ACE) 활성억제효과}

혈압상승과 관련된 기전의 일부는 혈압상승 유발효소인 $\mathrm{ACE}$ 에 의해 일어나는 것으로 알려져 있으며, $\mathrm{ACE}$ 는 불활성 형인 angiotensin I 에 작용하여 angiotensin $\Pi$ 를 생성함으로 서 혈압을 상승시키는 역할을 수행하는 효소이다. ACE저해제 는 ACE의 작용을 저해함으로써 angiotensin $\Pi$ 의 생성저해, aldosterone 분비 감소, 불활성형인 angiotensin I 의 $\mathrm{C}$ 말단에 존재하는 His-Leu을 절단하여 angiotensin II를 생성함으로 서 혈압을 감소시키는 역할을 수행하는 혈관확장제인 bradykinin의 증가 등의 과정을 통해 신장혈관을 확장시켜 sodium 의 배설을 촉진함으로써 혈압을 낮추어 주는 역할을 하는 것 으로, Bothrops jararaca 독사의 독에서 발견된 $\mathrm{BPFs}$, nonapeptide인 SQ20881 등이 우수한 ACE저해제로 개발되었다 [27]. 이후 $\mathrm{ACE}$ 의 강력한 저해제인 Captopril, Enalapril, Benazepril 등 수종의 $\mathrm{ACE}$ 저해제가 상품화되어 고혈압 치료 제로서 이용되고 있다[8]. 천연물에 의한 $\mathrm{ACE}$ 저해제로서는 peptide, flavonoid 배당체류 등의 보다 강력한 ACE 저해능을 갖는 천연물질에 대한 탐색이 지속적으로 이루어지고 있으며

Table 2. Phenolic contents of water and ethanol extracts from various mulberry fruits (Morus alba L.)

\begin{tabular}{lccccc}
\hline \multirow{2}{*}{ Samples } & \multicolumn{4}{c}{ Phenolics content $(\mathrm{mg} / \mathrm{g})$} \\
\cline { 2 - 5 } & \multirow{2}{*}{ Water extracts } & \multicolumn{4}{c}{ Ethanol extracts } \\
\cline { 2 - 5 } & & $20 \%$ & $40 \%$ & $60 \%$ & $80 \%$ \\
\hline Morus alba cv. Baekwoon III & $1.4 \pm 0.2$ & $1.3 \pm 0.1$ & $1.5 \pm 0.1$ & $1.6 \pm 0.1$ & $1.5 \pm 0.2$ \\
Morus alba cv. Daeyoupchosaeng & $1.5 \pm 0.1$ & $1.6 \pm 0.1$ & $1.9 \pm 0.2$ & $2.0 \pm 0.1$ & $1.9 \pm 0.1$ \\
Morus alba cv. Suwonppong & $1.8 \pm 0.1$ & $1.7 \pm 0.2$ & $1.8 \pm 0.1$ & $1.9 \pm 0.1$ & $1.9 \pm 0.1$ \\
Morus alba cv. Cheongilppong & $2.2 \pm 0.3$ & $1.8 \pm 0.2$ & $2.2 \pm 0.1$ & $2.3 \pm 0.1$ & $2.4 \pm 0.1$ \\
Morus alba cv. Daechoukmyeun & $1.1 \pm 0.1$ & $1.1 \pm 0.1$ & $1.2 \pm 0.1$ & $1.5 \pm 0.2$ & $1.4 \pm 0.1$ \\
Morus alba cv. Kangwon III & $2.9 \pm 0.2$ & $2.8 \pm 0.3$ & $3.0 \pm 0.2$ & $3.2 \pm 0.1$ & $3.2 \pm 0.3$ \\
Morus alba cv. Hihak & $1.9 \pm 0.1$ & $2.1 \pm 0.1$ & $2.5 \pm 0.4$ & $2.6 \pm 0.3$ & $2.7 \pm 0.2$ \\
Morus alba cv. Cataneo & $1.6 \pm 0.1$ & $1.6 \pm 0.2$ & $1.9 \pm 0.1$ & $2.2 \pm 0.1$ & $2.3 \pm 0.2$ \\
Morus alba cv. Kuksang 20 & $0.8 \pm 0.1$ & $1.1 \pm 0.1$ & $1.3 \pm 0.2$ & $1.5 \pm 0.1$ & $1.4 \pm 0.1$ \\
\hline
\end{tabular}

The data were expressed as the mean \pm SD. $(n=3)$. Results are representatives of more than six independent experiments. 
[25], 이러한 연구의 일환으로 오디 각 품종별로 물과 $60 \%$ 에 탄올 추출물의 $\mathrm{ACE}$ 활성억제효과를 탐색한 결과, Table 3에 서 보는 바와 같이 물추출물 $(200 \mu \mathrm{g} / \mathrm{ml}$ phenolics)에서는 백 운3호가 $90.9 \pm 4.5 \%$ 의 높은 $\mathrm{ACE}$ 저해율 나타내었고, 대엽조생, 수원뽕, 강원3호 및 희학 품종이 각각 $86.4 \pm 4.5 \%, 54.6 \pm 4.5 \%$, $45.5 \pm 9.1 \%, 54.6 \pm 4.5 \%$ 의 $\mathrm{ACE}$ 저해율을 나타내어 비교적 우수 한 항고혈압 활성을 나타내었다. 에탄올 추출물 $(200 \mu \mathrm{g} / \mathrm{ml}$ phenolics)의 경우 물추출물과는 다른 양상을 나타내었는데, 희학 품종이 $81.8 \pm 4.5 \%$ 의 높은 $\mathrm{ACE}$ 저해율을 나타내었고, 대 엽조생, 수원뽕, 대축면, 카타네오 품종에서 각각 $77.3 \pm 4.5 \%$, $72.7 \pm 4.5 \%, 72.7 \pm 4.5 \%, 68.2 \pm 4.5 \%$ 로 비교적 우수한 항고혈압 활성을 나타내었다. 추출물들의 $\mathrm{ACE}$ 저해활성은 현재 고혈압 치료제로 이용되고 있는 positive control인 captopril $(200 \mu \mathrm{g}$ $/ \mathrm{ml})$ 의 $59.1 \pm 4.5 \%$ 보다 더 우수한 억제효과를 나타내었다. An 등[1]과 $\mathrm{Kim}$ 등[17]의 연구보고에서 $\mathrm{ACE}$ 활성억제효과가 식 물자원의 특정 페놀 화합물의 작용에 의한 가능성이 높다는 보고와 Kamadae 등[13], Funayama 등[11]의 감나무 잎에서 분리한 다양한 phenol성 물질 중 flavonoid가 ACE 저해활성 을 가진다는 보고와 관련하여 오디추출물 중에 함유된 phenol 성 물질 중 $\mathrm{ACE}$ 에 작용하는 flavonoid 등의 물질들이 존재하 며, An 등[1]의 보고와 같이 특정 phenol 화합물들이 오디에 존재하는 것으로 판단되었다. 또한 오디 종류별로 $\mathrm{ACE}$ 저해 양상이 다른 것은 각 추출물에 존재하는 phenolic compound 들의 양과 더불어 phenolic profile이 다르기 때문으로 추정하 였으며, 어떤 phenolic compound가 존재하는가에 의해 고혈 압억제 효과의 양상은 다양하게 나타나리라 판단되었으며, 이 에 대한 연구는 차후에 진행되어야 할 것으로 판단되었다. 이 와 같이 여러 품종의 오디 추출물에서 $\mathrm{ACE}$ 에 대한 저해율이 높게 나타나 오디의 고혈압 예방 효과가 아주 우수할 것으로 생각되었으며, 산업화에 적용이 가능할 것으로 판단되었다.

\section{Xanthine Oxidase (XOase) 활성억제효과}

관절염 중 통풍(gout) 유발 효소인 XOase는 xanthine을 기 질로 하여 uric acid를 생성하는 과정에서 superoxide radical 을 생성하는(free radical generation)효소이다. 생체내 유리기 생성계의 하나인 XOase는 purine, pyrimidine, pteridine, aldehyde류 및 heterocyclic compound 등의 대사에 관여하는 비특이적 효소로서 생체내에서는 주로 purine체의 대사산물 인 hypoxanthine을 xanthine으로, xanthine을 다시 산화시켜 uric acid를 생성하는 반응의 촉매로 작용한다[34]. 통풍은 uric acid의 수치가 높기 때문에 일어나며 uric acid가 결정체를 이 루어 관절에 달라붙어 염증이 생기며, 심한 경우 신장이나 심 장 등에 합병증을 유발하기도 한다[6]. 따라서 XOase저해제는 통풍, 신장결석, 심근증을 일으키는 요산혈증(hyperuricemia) 에 대한 치료제로 사용되어 왔으며, 통풍의 치료를 위하여 XOase 저해제의 필요성이 증대되고 있다. 본 연구에서는 9종 의 오디 품종의 물추출물 $(200 \mu \mathrm{g} / \mathrm{ml})$ 과 $60 \%$ 에탄올 추출물 $(200 \mu \mathrm{g} / \mathrm{ml})$ 로부터 XOase활성 억제효과를 탐색한 결과, Table 4 에서와 같이 물 추출물에서는 국상 20 호에서만 $10 \%$ 내 외의 낮은 XOase 저해 활성을 나타내었고, 에탄올 추출물에서 는 카타네오 품종이 $21.4 \pm 2.3 \%$ 의 저해율을 나타내었다. 추출 물들의 통풍억제 효과는 현재 통풍 치료제로 이용되고 있는 positive control인 allopurinol $(200 \mu \mathrm{g} / \mathrm{ml})$ 의 $68.2 \pm 1.2 \%$ 와 비 교하면 낮은 억제효과를 나타내었으나, 정제를 통하여 순도를 높인다면 통풍 치료제로의 활용 가능성도 기대할 수 있을 것 이라 판단되었다. 그 이외의 품종에서는 카타네오 품종이 약 $7 \%$ 의 저해효과를 나타내었을 뿐 통풍 억제 효과는 높지 않은 것으로 확인 되었다. 이와 같은 결과는 식물계에 존재하는 phenol성물질의 생리활성이 hydroxy기의 위치에 따라 각종 효소의 저해효과가 다르다는 연구보고와[12], 구조적으로 gal-

Table 3. Inhibitory activity of water and ethanol extracts from various mulberry fruits (Morus alba L.) against angiotensin converting enzyme

\begin{tabular}{|c|c|c|c|c|}
\hline \multirow{3}{*}{ Samples } & \multicolumn{4}{|c|}{ Inhibitory activity (\%) } \\
\hline & \multicolumn{2}{|c|}{ Water extracts } & \multicolumn{2}{|c|}{$60 \%$ Ethanol extracts } \\
\hline & $\mathrm{HA}^{1)}(\mu \mathrm{g} / \mathrm{ml})$ & $\mathrm{IA}^{2)}(\%)$ & HA $(\mu \mathrm{g} / \mathrm{ml})$ & IA $(\%)$ \\
\hline Control & $2.2 \pm 0.2$ & - & $2.2 \pm 0.2$ & - \\
\hline Morus alba cv. Baekwoon III & $0.2 \pm 0.1$ & $90.9 \pm 4.5$ & $2.4 \pm 0.2$ & 0 \\
\hline Morus alba cv. Daeyoupchosaeng & $0.3 \pm 0.1$ & $86.4 \pm 4.5$ & $0.5 \pm 0.1$ & $77.3 \pm 4.5$ \\
\hline Morus alba cv. Suwonppong & $1.0 \pm 0.1$ & $54.6 \pm 4.5$ & $0.6 \pm 0.1$ & $72.7 \pm 4.5$ \\
\hline Morus alba cv. Cheongilppong & $1.6 \pm 0.1$ & $27.3 \pm 4.5$ & $2.2 \pm 0.3$ & 0 \\
\hline Morus alba cv. Daechoukmyeun & $1.5 \pm 0.1$ & $31.8 \pm 4.5$ & $0.6 \pm 0.1$ & $72.7 \pm 4.5$ \\
\hline Morus alba cv. Kangwon III & $1.2 \pm 0.2$ & $45.5 \pm 9.1$ & $1.9 \pm 0.1$ & $13.6 \pm 4.5$ \\
\hline Morus alba cv. Hihak & $1.0 \pm 0.1$ & $54.6 \pm 4.5$ & $0.4 \pm 0.1$ & $81.8 \pm 4.5$ \\
\hline Morus alba cv. Cataneo & $3.5 \pm 0.2$ & 0 & $0.7 \pm 0.1$ & $68.2 \pm 4.5$ \\
\hline Morus alba cv. Kuksang 20 & $1.4 \pm 0.1$ & $36.4 \pm 4.5$ & $1.5 \pm 0.2$ & $31.8 \pm 9.1$ \\
\hline Positive control (Captopril) & $0.9 \pm 0.1$ & $59.1 \pm 4.5$ & $0.9 \pm 0.1$ & $59.1 \pm 4.5$ \\
\hline
\end{tabular}

${ }^{1)}$ Hippuric acid, ${ }^{2)}$ Inhibitory activity.

The data were expressed as the mean \pm SD. $(n=3)$. 
loyl기를 함유한 flavonoid 화합물이 함유하지 않은 화합물에 비해 XOase 저해효과가 우수하였으며 경쟁적으로 저해한다 고 보고한[29] 사실을 토대로 오디추출물 중에는 phenol성 물 질의 함량은 비교적 높은 편이나, $\mathrm{An}$ 등[1]의 보고와 같이 XOase의 억제 mechanism에 작용하는 특정 phenolic profile 이 오디에는 다량으로 존재하지 않기 때문에 phenol 화합물의 함량은 높으나 XOase에 대한 저해 효과는 높지 않은 것으로 판단되었다.

\section{a-Amylase 저해효과}

탄수화물 대사 작용에 필수적인 효소인 a-amylase에 대하 여 다양한 품종의 오디로부터 물 추출물 $(200 \mathrm{\mu g} / \mathrm{ml})$ 과 $60 \%$ ethanol 추출물 $(200 \mu \mathrm{g} / \mathrm{ml})$ 이 a-amylase 작용을 얼마만큼 억 제하여 당 분해효과를 낮출 수 있는지를 실험해 본 결과, Table
5 에서와 같이 대축면 품종을 제외한 모든 시료의 물추출물에 서 $80 \%$ 이상의 매우 높은 a-amylase에 대한 저해양상이 확인 되었으며, 특히 대엽조생, 수원뽕, 청일뽕, 강원 3 호, 희학 및 국상 20 등의 품종은 거의 완벽하게 a-amylase를 억제하는 것 으로 확인되었다. 또한 에탄올 추출물에서는 청일뽕 만이 $14.9 \pm 5.3 \%$ 의 낮은 억제효과를 나타내었을 뿐 나머지 모든 품 종에서 모두 $80 \%$ 가까운 높은 억제효과가 확인되었다. Cho 등[4]은 오미자 추출물이 a-amylase 억제효과가 물과 $60 \%$ ethanol 추출물에서 모두 $100 \%$ 의 저해율을 나타내었다고 보 고하였고, Lee 등[23]은 안토시아닌, proantocyanidins 등과 같 은 phenol성 물질이 a-amylase 저해활성 효과가 있다고 하였 으며, 본 연구에서도 a-amylase에 대한 비교적 높은 저해효과 를 나타낸 오디품종의 추출물속의 phenolic compound에 의 해서 a-amylase 저해 활성을 나타내는 것으로 추측되었다. 이

Table 4. Inhibitory activity of water and ethanol extracts from various mulberry fruits (Morus alba L.) against xanthine oxidase

\begin{tabular}{lcccc}
\hline \multirow{2}{*}{ Samples } & \multicolumn{3}{c}{ Inhibitory activity (\%) } \\
\cline { 2 - 5 } & \multicolumn{2}{c}{ Water extracts } & \multicolumn{2}{c}{$60 \%$ Ethanol extracts } \\
\cline { 2 - 5 } & $\mathrm{UA}^{1)}(\mathrm{\mu g} / \mathrm{ml})$ & $\mathrm{IA}^{2)}(\%)$ & $\mathrm{UA}(\mathrm{\mu g} / \mathrm{ml})$ & IA (\%) \\
\hline Control & $17.3 \pm 0.3$ & - & $17.3 \pm 0.3$ & - \\
Morus alba cv. Baekwoon III & $20.8 \pm 0.5$ & 0 & $16.8 \pm 1.1$ & $2.9 \pm 6.4$ \\
Morus alba cv. Daeyoupchosaeng & $20.3 \pm 0.2$ & 0 & $17.4 \pm 0.6$ & 0 \\
Morus alba cv. Suwonppong & $20.1 \pm 0.3$ & 0 & $19.2 \pm 1.3$ & 0 \\
Morus alba cv. Cheongilppong & $17.2 \pm 0.3$ & $0.6 \pm 1.7$ & $17.2 \pm 0.4$ & $0.6 \pm 2.3$ \\
Morus alba cv. Daechoukmyeun & $23.2 \pm 1.2$ & 0 & $20.0 \pm 0.3$ & 0 \\
Morus alba cv. Kangwon III & $23.5 \pm 0.8$ & 0 & $20.2 \pm 0.8$ & 0 \\
Morus alba cv. Hihak & $19.9 \pm 0.7$ & 0 & $21.2 \pm 0.6$ & 0 \\
Morus alba cv. Cataneo & $16.1 \pm 0.3$ & $6.9 \pm 1.7$ & $13.6 \pm 0.4$ & $21.4 \pm 2.3$ \\
Morus alba cv. Kuksang 20 & $15.6 \pm 0.5$ & $9.8 \pm 2.9$ & $17.2 \pm 0.3$ & $0.6 \pm 1.7$ \\
Positive control (Allopurinol) & $5.5 \pm 0.2$ & $68.2 \pm 1.2$ & $5.5 \pm 0.2$ & $68.2 \pm 1.2$ \\
\hline Uric
\end{tabular}

${ }^{1)}$ Uric acid, ${ }^{2)}$ Inhibitory activity.

The data were expressed as the mean $\pm S D$. $(n=3)$.

Table 5. Inhibitory activity of water and ethanol extracts from various mulberry fruits (Morus alba L.) against a-amylase

\begin{tabular}{|c|c|c|c|c|c|c|}
\hline \multirow{3}{*}{ Samples } & \multicolumn{6}{|c|}{ Inhibitory activity (\%) } \\
\hline & \multicolumn{3}{|c|}{ Water extracts } & \multicolumn{3}{|c|}{$60 \%$ Ethanol extracts } \\
\hline & $\begin{array}{c}\text { Clear zone } \\
\left(\mathrm{cm}^{2}\right)\end{array}$ & $\begin{array}{l}\text { a-Amylase } \\
\text { (Unit/ml) }\end{array}$ & $\begin{array}{c}\text { Inhibitory } \\
\text { activity (\%) }\end{array}$ & $\begin{array}{c}\text { Clear zone } \\
\left(\mathrm{cm}^{2}\right)\end{array}$ & $\begin{array}{l}\text { a-Amylase } \\
\text { (Unit/ml) }\end{array}$ & $\begin{array}{l}\text { Inhibitory } \\
\text { activity (\%) }\end{array}$ \\
\hline Control & $9.4 \pm 0.2$ & $200.0 \pm 4.3$ & - & $9.4 \pm 0.2$ & $200.0 \pm 4.3$ & - \\
\hline Morus alba cv. Baekwoon III & $1.7 \pm 0.2$ & $36.2 \pm 4.3$ & $81.9 \pm 2.1$ & $2.0 \pm 0.4$ & $42.6 \pm 8.5$ & $78.7 \pm 4.3$ \\
\hline Morus alba cv. Daeyoupchosaeng & 0 & 0 & 100.0 & $2.0 \pm 0.2$ & $42.6 \pm 4.3$ & $78.7 \pm 2.1$ \\
\hline Morus alba cv. Suwonppong & 0 & 0 & 100.0 & $2.0 \pm 0.2$ & $42.6 \pm 4.3$ & $78.7 \pm 2.1$ \\
\hline Morus alba cv. Cheongilppong & 0 & 0 & 100.0 & $8.0 \pm 0.5$ & $170.2 \pm 10.6$ & $14.9 \pm 5.3$ \\
\hline Morus alba cv. Daechoukmyeun & $7.3 \pm 0.6$ & $155.3 \pm 12.8$ & $22.3 \pm 6.4$ & $2.0 \pm 0.1$ & $42.6 \pm 1.1$ & $78.7 \pm 1.1$ \\
\hline Morus alba cv. Kangwon III & 0 & 0 & 100.0 & $2.1 \pm 0.2$ & $44.7 \pm 4.3$ & $77.7 \pm 2.1$ \\
\hline Morus alba cv. Hihak & 0 & 0 & 100.0 & $2.0 \pm 0.3$ & $42.6 \pm 6.4$ & $78.7 \pm 3.2$ \\
\hline Morus alba cv. Cataneo & $1.8 \pm 0.3$ & $38.3 \pm 6.4$ & $81.1 \pm 3.2$ & $2.0 \pm 0.2$ & $42.6 \pm 4.3$ & $78.7 \pm 2.1$ \\
\hline Morus alba cv. Kuksang 20 & 0 & 0 & 100.0 & $2.1 \pm 0.1$ & $44.7 \pm 1.1$ & $77.7 \pm 1.1$ \\
\hline Positive control (Camellia sinensis) & 0 & 0 & 100.0 & 0 & 0 & 100.0 \\
\hline
\end{tabular}

The data were expressed as the mean \pm SD. $(n=3)$. 
Table 6. Inhibitory activity of water and ethanol extracts from various mulberry fruits (Morus alba L.) against a-glucosidase

\begin{tabular}{lcccc}
\hline \multirow{2}{*}{ Samples } & \multicolumn{3}{c}{ Inhibitory activity $(\%)$} \\
\cline { 2 - 4 } & \multicolumn{2}{c}{ Water extracts } & \multicolumn{2}{c}{$60 \%$ Ethanol extracts } \\
\cline { 2 - 4 } & $\mathrm{PN}^{1)}(\mathrm{\mu g} / \mathrm{ml})$ & $\mathrm{IA}^{2)}(\%)$ & PN $(\mathrm{\mu g} / \mathrm{ml})$ & IA $(\%)$ \\
\hline Control & $6.2 \pm 0.5$ & $30.7 \pm 4.8$ & $6.2 \pm 0.5$ & - \\
Morus alba cv. Baekwoon III & $4.3 \pm 0.3$ & $19.4 \pm 4.8$ & $6.4 \pm 1.1$ & 0 \\
Morus alba cv. Daeyoupchosaeng & $5.0 \pm 0.3$ & $8.1 \pm 3.2$ & $6.2 \pm 0.3$ & 0 \\
Morus alba cv. Suwonppong & $5.7 \pm 0.2$ & $22.6 \pm 3.2$ & $5.9 \pm 0.2$ & 0 \\
Morus alba cv. Cheongilppong & $4.8 \pm 0.2$ & $17.7 \pm 4.8$ & $4.7 \pm 0.2$ & $4.8 \pm 3.2$ \\
Morus alba cv. Daechoukmyeun & $5.1 \pm 0.3$ & 0 & $4.9 \pm 0.4$ & $24.2 \pm 3.2$ \\
Morus alba cv. Kangwon III & $6.3 \pm 0.7$ & $33.9 \pm 3.2$ & $5.8 \pm 0.3$ & $21.0 \pm 6.5$ \\
Morus alba cv. Hihak & $4.1 \pm 0.2$ & $4.8 \pm 3.2$ & $5.3 \pm 0.1$ & $6.5 \pm 4.8$ \\
Morus alba cv. Cataneo & $5.9 \pm 0.2$ & 0 & $5.0 \pm 0.2$ & $14.5 \pm 1.6$ \\
Morus alba cv. Kuksang 20 & $7.2 \pm 1.1$ & $40.3 \pm 4.8$ & $3.7 \pm 0.3$ & $19.4 \pm 3.2$ \\
Positive control (Acarbose) & $3.7 \pm 0.3$ & & $40.3 \pm 4.8$ \\
\hline
\end{tabular}

${ }^{10} \mathrm{p}$-Nitrophenol(PN), ${ }^{2}$ Inhibitory activity.

The data were expressed as the mean $\pm \mathrm{SD}$. $(\mathrm{n}=3)$.

와같이 물추출물과 에탄올 추출물에서 대단히 높은 $a$ -amylase 억제효과가 확인됨에 따라 오디를 당뇨억제효과를 활용한 산업화에 적용시킬 수 있는 소재로 개발이 기능할 것 으로 판단되었다.

\section{a-Glucosidase 저해효과}

품종별 오디 추출물을 대상으로 효모기원의 a-glucosidase 활성저해 효과를 측정한 결과, Table 6과 같이 물 추출물(200 $\mu \mathrm{g} / \mathrm{ml}$ )에서 희학 및 백운 3 호 품종에서 각각 $33.9 \pm 3.2 \%$ 와 $30.7 \pm 4.8 \%$ 의 a-glucosidase 활성저해 효과를 확인하였으며, 대 엽조생, 청일뽕 등은 $20 \%$ 이상의 억제효과를 가지는 것으로 측정되었다. 또한 에탄올 추출물에서는 대축면, 강원3호 및 국상 20 호 품종에서 $20 \%$ 이상의 a-glucosidase 억제활성을 확 인할 수 있었으며, 희학 품종의 경우 현재 당뇨병 치료제로 이용되고 있는 positive control인 acarbose $(200 \mu \mathrm{gg} / \mathrm{ml})$ 와 유 사한 억제효과를 나타내었다. Kim 등[16]은 산사추출물의 $a$ -glucosidase 저해활성이 $60 \% \mathrm{ethanol} \mathrm{추출물보다} \mathrm{물} \mathrm{추출물}$ 에서 높은 저해활성을 나타낸다고 보고하였고, Lee 등[23]은 proanthocyanidin이 탄수화물과 관련한 효소의 일부 기능을 억제하고 있다고 보고하고 기존의 식물 유래의 억제물질은 대부분 단백질과 관련된 물질이지만 proanthocyanidin은 phenol 계통의 물질로 a-amylase 및 a-glucosidase의 활성을 저해한다고 보고하였다. 이와 같이 오디 추출물의 phenolic compound도 이러한 탄수화물 분해 효소의 활성을 억제하는 것으로 확인되었다.

\section{감사의 글}

이 연구는 지식경제부에서 시행한 지역산업기술개발사업(중 점기술개발사업)의 기술개발 결과이며, 연구개발비 지원에 감
사드립니다.

\section{References}

1. An, B. J. and Lee, J. T. 1999. Isolation and characterization of angiotensin converting enzyme inhibitors from Camellia sinensis L. and their chemical structure determination. Food Sci. Biotechnol. 8, 285-289.

2. Cha, J. Y., Kim, H. J., Chung, C. H. and Cho, Y. S. 1999. Antioxidative activites and contens of polyphenolic compound of Cudrania tricuspodata. J. Kor. Soc. Food Sci. Nutr. 28, 1310- 1314.

3. Cho, Y. J., Ju, I. S., Chun, S. S., An, B. J., Kim, J. H., Kim, M. U. and Kwon, O. J. 2008. Screening of biological activities of extracts from Rhododendron mucronulatum Turcz. flowers. J. Kor. Soc. Food Sci. Nutr. 37, 276-281.

4. Cho, Y. J., Ju, I. S., Kim, B. C., Lee, W. S., Kim, M. J., Lee, B. G., An, B. J., Kim, J. H. and Kwon, O. J. 2007. Biological activity of Omija extracts. J. Kor Soc. Appl. Chem 50, 198-203.

5. Cushman, D. W. and Ondetti, M. A. 1980. Inhibitors of angiotensin converting enzyme for treatment of hypertension. Biochem Pharmacol. 29, 1871-1877.

6. Duke, E. J., Joyce, P. and Ryan, J. P. 1973. Characterization of alternative molecular forms of xanhine oxidase in the mouse. J. Biochem 131, 187-193.

7. Duval, B. and Shetty, K. 2001. The stimulation of phenolics and antioxidant activity in pea (Pisum sativum) elicited by genetically transformed Anise (Pimpinella anisum L.) root extract. J. Food Biochem 25, 361-377.

8. Engel, S. L., Schaeffer, T. R., Gold, B. I. and Rubin, B. 1972. Inhibition of pressure effects of angiotensin $I$ and augmentation of depressor effects of breadykinin by synthetic peptides. Proc. Soc. Exp. Biol. Med. 140, 240-245.

9. Feng, G. H., Richardson, M., Chen, M. S., Kramer, K. J., Morgan, T. D. and Reek, G. R. 1996. Amylase inhibitors from wheat: Amino acid sequences and patterns of in- 
hibition of insect and human a-amylases. Insect Biochem Mol. Biol. 26, 419-426.

10. Fridovich, I. 1986. Biological effects of the superoxide radical. Arch Biochem Biophys. 247, 1-15.

11. Funayama, S. and Hikono, H. 1979. Hypoemsive principles of Diospyors kaki Leaves. Chem Pharm Bull. 27, 2865-2871.

12. Hayashi, T., Sawa, K. and Morita, N. 1988. Inhibition of cow's milk xanthine oxidase by flavonoids. J. Natural Prod 51, 345-351.

13. Kameda, K., Takaku, T., Okyada, H. and Kimura, H. 1987. Inhibitory effects of various flavonoids isolated from leaves of persimmon on angiotensin-converting enzyme activity. J. Natural Prod 50, 680-687.

14. Kim, H. B., Kim, S. Y., Ryu, K. S., Lee, W. C. and Moon, J. Y. 2001. Effect of methanol extract from mulberry fruit on the lipid metabolism and liver function in cholesterol induced hyperlipidemia rats. Kor. J. Seric. Sci. 43, 104-107.

15. Kim, H. B., Lee, Y. W., Lee, W. J. and Moon, J. Y. 2001. Physiological effects and sensory characteristics of Mulberry fruit wine with chongilppong. Kor. J. Seric. Sci. 43, 16-20.

16. Kim, J. H., Kim, M. U. and Cho, Y. J. 2007. Isolation and identification of inhibitory compound from Crataegi fructus on a-amylase and a-glucosidase. J. Kor. Soc. Appl. Biol. Chem 50, 204-209.

17. Kim, K. M., Suh, H. J., Chung, S. H., Cho, W. D. and Ma, S. J. 1999. Chemical structure of angiotensin converting enzyme inhibitor isolated from onion flesh. Food Sci. Biotechnol. 8, 329-332.

18. Kim, S. K. 1991. Benefical medicine, mulberry fruit. In Bonchohak Younglimsa, Seoul, Korea. pp. 598-605.

19. Kim, S. Y., Park, K. Y. and Lee, W. C. 1998. Antiinflammatory and antioxidative effects of Morus spp. fruit extract. Kor. J. Med Crop Sci. 6, 204-209.

20. Kim, T. Y. and Kwon, Y. B. 1996. A study on the antidiabetic effect of mulberry fruits. Kor. J. Seri. Sci. 38, 100-104.

21. Lee, S. E., Bang, J., Song, J., Seong, N. S., Park, H. W., Chung, H. G. and An, T. J. 2004. Inhibitory activity on angiotensin converting enzyme (ACE) of korean medicinal herbs. Kor. J. Medkinial Crop Sci. 12, 73-78.

22. Lee, W. C., Kim, A. J. and Kim, S. Y. 2003. The study on the functional materials and effects of mulberry leaf. Food Sci. Indust. 36, 2-14.

23. Lee, W. Y., Ahn, J. K., Park, Y. K. and Rhee, H. I. 2004. Inhibitory effects of proanthocynidin extracted from distylium racemosum of a-amylase and a-glucosidase activities. Kor. J. Pharmacogn. 35, 271-275.

24. Markwick, N. P., Laing, W. A., Cristeller, J. T., Reid, S. J. and Netwton, M. R. 1996. a-Amylase activities in larval midgut extraxcts from four species of Lepidoptera (Tortricidae and Gelechiidae): Response to $\mathrm{pH}$ and to inhibitors from wheat, barley, kidney bean, and streptomyces. J. Econ. Entomol. 89, 39-45.

25. Maruyama, S., Nakagomi, K., Tomizuka, N. and Suzuki, H. 1985. Angiotensin converting enzyme inhibitor derived from an enzymatic hydrolysate of casein. Agric. Biol. Chem 49, 1405-1410.

26. Moon, S. J. and Hong, S. M. 1996. A study on the relation between psychological stress and stress hormone, nutritional status of patients with non-insulin dependent diabetes mellitus. Kor. J. Nutr. 29, 889-898.

27. Noh, H. and Song, K. B. 2001. Isolation of an angiotensin converting enzyme inhibitor from Oenanthe javanica. Agric. Chem Biotechnol. 44, 98-99.

28. Park, S. W., Chung, Y. S., Yun, Y. S., Cha, B. S., Song, Y. D., Lee, H. C. and Huh, K. B. 1998. Insulin resistance and relate factors in the healthy young men. Diabetes 22, 504-512.

29. Ra, K. S., Bae, S. H., Son, H. S., Chung, S. H. and Suh, H. S. 1998. Inhibition of xanthine oxidase by flavonoids from onion skin. J. Kor. Soc. Food Sci. Nutr. 27, 693-697.

30. Robert, I. L. 1994. In Functional Foods Phytochemicals and antioxidants. Goldberg, I. (Ed) Chapman \& Hall, New York pp.393.

31. Sato, M., Ramarathnam, N., Suzuki, Y., Ohkubo, T., Takeuchi, M. and Ochi, H. 1996. Varietal differences in the phenolic content and superoxide radical scavenging potential of wines from different sources. J. Agric. Food Chem 44, 37-41.

32. Stirpe, F. and Corte, E. D. 1969. The regluation of rat liver xanthine oxidase. J. Biol. Chem 244, 3855-3863.

33. Tibbot, B. K. and Skadsen, R. W. 1996. Molecular cioning and characeriwation of a gibberellin-inducible, putative a -glucosidase gene from berley. Plant Mol. Biol. 30, 229-241.

34. Ziegler, D. W., Hutchison, H. D. and Kissing, R. E. 1971. Induction of xanthine oxidase by virus infections in newborn mice. Infect. Immun. 3, 237-242.

35. Zielinski, H. and Kozlowska, H. 2000. Antioxidant activity and total phenolics in selseted cereal grains and their different morphological fractions. J. Agric. Food Chem 48, 2008-2010. 
초록 : 품종이 다른 오디(Morus alba L.)의 성인병 관련 효소 억제효과

채정우 ${ }^{1} \cdot$ 박혜진 $^{2} \cdot$ 강선애 ${ }^{2} \cdot$ 차원섭 $^{3} \cdot$ 안동현 $^{4} \cdot$ 조영제 ${ }^{3}{ }^{*}$

( ${ }^{1}$ 경기도산림환경연구소, P경북대학교 응용생명과학부, ${ }^{3}$ 경북대학교 식품공학부/식품생물산업연구소, ${ }^{4}$ 부 경대학교 식품공학과/식품연구소)

생리활성을 갖는 새로운 기능성 물질을 개발할 목적으로 9종의 오디(Morus alba L.)를 이용하여 물과 $60 \%$ 에탄 올 추출물을 제조하고 이들의 angiotensin converting enzyme 활성억제효과, xanthine oxidase 활성억제효과, $a$ -amylase 활성억제효과 및 a-glucosidase 활성억제효과를 탐색하여 본 결과, 페놀함량이 청일뽕과 강원3호 품종 의 오디에서 물추출물에서 청일뽕과 강원 3 호 두품종이, 에탄올 추출물에서 대엽조생, 청일뽕, 강원 3 호, 희학 및 카타네오 등 5 품종이 $2 \mathrm{mg} / \mathrm{g}$ 이상의 phenolic compound 함량을 나타내었으며, angiotensin converting enzyme 활성억제효과는 물 추출물에서 백운 3 호가 $90.9 \pm 4.5 \%$, 에탄올 추출물에서는 희학 품종이 $81.8 \pm 4.5 \%$ 의 활성억제효 과를 나타내었다. 또한 xanthine oxidase 활성억제효과는 물 추출물에서 국상 20 호가 약 $10 \%$ 정도, 에탄올 추출물 에서는 카타네오가 $21.4 \pm 2.3 \%$ 의 활성억제효과를 나타내었다. 당분해활성에 관여하는 $a$-amylase와 a-glucosidase 활성억제효과를 측정해 본 결과 물추출물에서만 대엽조생, 수원뽕, 청일뽕, 강원 3 호, 희학 및 국상 20 호 등 6 품종 이 $100 \%$ 의 a-amylase 저해효과가 관찰되었으며, 백운 3 호, 대엽조생, 청일뽕 및 희학은 물추출물에서, 대축면, 강 원3호 및 국상 20 호는 에탄올 추출물에서 $20 \%$ 이상의 a-glucosidase 저해효과가 확인되었다. 이상의 결과, 높은 생리활성기능을 나타내는 여러 종의 오디의 물과 에탄올 추출물들은 항고혈압 및 항당뇨 효과가 있는 기능성 식품소재로 활용할 수 있을 것으로 판단되었다. 